\title{
PENGEMBANGAN MEDIA PEMBELAJARAN GAYA DAN TEKANAN UNTUK SISWA SEKOLAH MENENGAH PERTAMA KELAS VII
}

\author{
Oleh \\ Ni Wayan Marti \\ Jurusan Manajemen Informatika, FTK, Undiksha
}

\begin{abstract}
ABSTRAK
Multimedia pembelajaran merupakan komponen sistem penyampaian pengajaran yang dapat digunakan dalam mendukung proses pembelajaran. Pengembangan multimedia dilandasi oleh persepsi bahwa pembelajaran akan berlangsung dengan baik, efektif, dan menyenangkan jika didukung oleh media pembelajaran yang dapat menarik minat dan perhatian siswa. Oleh karena itu, pengembang perlu memahami konsep, model, prinsip, desain, dan evaluasi multimedia pembelajaran.

Salah satu produk teknologi yang dapat digunakan sebagai inovasi dalam pembelajaran adalah komputer. Komputer sebagai salah satu produk teknologi dinilai tepat digunakan sebagai alat bantu pengajaran. Keberadaan komputer yang telah meluas sampai tingkat sekolah menengah saat ini belum banyak digunakan untuk meningkatkan prestasi khususnya dalam pembelajaran Fisika. Dalam pembelajaran Fisika dalam hal ini materi Gaya dan Tekanan sangat membutuhkan pemahaman yang tinggi dari siswa. Sehingga perlu dibantu oleh suatu media pembelajaran yang didesain menarik dan dilengkapi dengan animasi, audio, maupun video sehingga proses pembelajaran akan berjalan dengan suasana baik dan tidak membosankan. Media pembelajaran gaya dan tekanan ini dikembangkan menggunakan perangkat lunak Macromedia Flash.
\end{abstract}

Kata-kata Kunci : Media Pembelajaran, Gaya dan Tekanan, Multimedia dan Macromedia Flash

\begin{abstract}
Instructional multimedia is a teaching component delivery systems that can be used in supporting the learning process. Multimedia
\end{abstract}

Pengembangan Media Pembelajaran Gaya................( Ni Wayan Marti) 
development based on the perception that learning will take place with good, effective, and enjoyable if they are supported by instructional media that can attract students' interest and attention. Therefore, developers need to understand the concepts, models, principles, design, and evaluation of multimedia learning.

One of the technology products that can be used as an innovation in teaching is the computer. Computers as one product is considered appropriate to use technology as a teaching tool. The existence of a computer that has spread to the secondary school level has not been widely used to improve learning achievement, especially in Physics. In learning physics in this material and Pressure Style desperately need a high understanding of students. So that needs to be assisted by an instructional media designed attractive and equipped with animation, audio, or video so that the learning process will run with good atmosphere and not boring. Media learning styles and this pressure was developed using Macromedia Flash software.

Keywords : Instructional Media, Material and Pressure Style, Multimedia, Macromedia Flash

\section{PENDAHULUAN}

Dewasa ini perkembangan ilmu dan tekonologi begitu pesatnya, laju perkembangan itu demikian luasnya hingga hampir mencakup seluruh kehidupan manusia. Khususnya di bidang teknologi informasi dan komunikasi inilah yang melatarbelakangi perlunya penerapan iptek di bidang pendidikan.

Sekolah sebagai suatu lembaga pendidikan yang mencetak kaderkader pembangunan bangsa dituntut dapat menyesuaikan dengan perubahan-perubahan yang sedang terjadi saat ini. Tantangan bagi sekolah untuk bisa menciptakan anak-anak didik yang mengenal dan mampu mengatasi ketertinggalannya akan ilmu pengetahuan dan teknologi.

Berdasarkan hasil penelitian, bahwa pembelajaran yang berlangsung di sekolah terutama di sekolah menengah pertama (SMP) selama ini masih bersifat konvensional. Dalam mengajar guru hanya mengandalkan metode ceramah secara klasikal. Guru kurang menggunakan media pendukung selain buku. Metode pembelajaran 
seperti ini kurang memenuhi prinsip-prinsip pembelajaran yang efektif dan kurang memberdayakan potensi siswa. Kegiatan belajar mengajar seharusnya mampu mengoptimalkan semua potensi siswa untuk menguasai kompetensi yang diharapkan. Proses belajar mengajar sebaiknya dilandasi dengan prinsip-prinsip: (1) berpusat pada siswa, (2) mengembangkan kreativitas siswa, (3) menciptakan kondisi menyenangkan dan menantang, (4) mengembangkan beragam kemampuan yang bermuatan nilai, (5) menyediakan pengalaman belajar yang beragam, dan (6) belajar melalui berbuat.

Berdasarkan hal tersebut di atas, baik guru maupun siswa di sekolah memerlukan adanya inovasi media pembelajaran. Inovasi media pembelajaran tersebut digunakan untuk meningkatkan kualitas pembelajaran. Salah satu produk teknologi yang dapat digunakan sebagai inovasi dalam pembelajaran adalah komputer. Hal tersebut sesuai dengan pernyataan Herman Dwi Surjono (1995) bahwa komputer sebagai salah satu produk teknologi dinilai tepat digunakan sebagai alat bantu pengajaran. Keberadaan komputer yang telah meluas sampai tingkat sekolah menengah saat ini belum banyak digunakan untuk meningkatkan prestasi khususnya dalam pembelajaran Fisika. Keadaan ini sejalan dengan pernyataan Herman Dwi Surjono (1995) bahwa penggunaan komputer dalam bidang pendidikan hingga saat ini belum maksimal.

Multimedia pembelajaran merupakan komponen sistem penyampaian pengajaran yang dapat digunakan dalam mendukung proses pembelajaran. Pengembangan multimedia dilandasi oleh persepsi bahwa pembelajaran akan berlangsung dengan baik, efektif, dan menyenangkan jika didukung oleh media pembelajaran yang dapat menarik minat dan perhatian siswa. Oleh karena itu, pengembang perlu memahami konsep, model, prinsip, desain, dan evaluasi multimedia pembelajaran.

Adapun tujuan dari penelitian ini adalah membangun sebuah media pembelajaran gaya dan tekanan berbasis multimedia yang ditujukan untuk siswa sekolah menengah pertama kelas VII. Media ini dikemas 
dalam bentuk CD interaktif sehingga dapat digunakan untuk belajar di rumah atau dimana saja selain di sekolah. Media pembelajaran gaya dan tekanan ini dibangun menggunakan perangkat lunak Macromedia Flash.

\section{LANDASAN TEORI}

\subsection{Pengertian Media Pembelajaran}

Pembelajaran Kata media berasal dari bahasa Latin, yakni medius yang secara harafiahnya berarti "tengah, pengantar atau perantara". Menurut Soeparno (1988), media adalah suatu alat yang dipakai sebagai saluran (channel) untuk menyampaikan pesan (message) atau informasi dari suatu sumber (resource) kepada penerimanya (reciever). Melalui Akhmad (2008), beberapa ahli memberikan definisi tentang media pembelajaran sebagai berikut. Schramm (1977) mengemukakan bahwa media pembelajaran adalah teknologi pembawa pesan yang dapat dimanfaatkan untuk keperluan pembelajaran. Sementara itu, Briggs (1977) berpendapat bahwa media pembelajaran adalah sarana fisik untuk menyampaikan isi/materi pembelajaran seperti : buku, film, video dan sebagainya. Sedangkan, National Education Associaton (1969) mengungkapkan bahwa media pembelajaran adalah sarana komunikasi dalam bentuk cetak maupun pandang-dengar, termasuk teknologi perangkat keras. Brown (1973) mengungkapkan bahwa media pembelajaran yang digunakan dalam kegiatan pembelajaran dapat mempengaruhi terhadap efektivitas pembelajaran. Menurut Munadi, media pembelajaran dapat dipahami sebagai segala sesuatu yang dapat menyampaikan dan meyalurkan pesan dari berbagai sumber secara terencana sehingga tercipta lingkungan belajar yang kondusif sehingga penerimanya dapat melakukan proses belajar secara efisien dan efektif. Dari beberapa pendapat para ahli di atas dapat disimpulkan bahwa media pembelajaran adalah sesuatu yang dapat menyampaikan dan meyalurkan pesan dari berbagai sumber secara terencana sehingga tercipta lingkungan 
belajar yang kondusif sehingga penerimanya dapat melakukan proses belajar secara efisien dan efektif.

\subsection{Jenis Media Pembelajaran}

Jenis media pembelajaran sangatlah beragam. Banyak ahli mengkategorikan media pembelajaran secara berbeda-beda. Menurut Paul dan David, (melalui Dewi dalam Gatra, 2007) mengkategorikan media menjadi enam kategori, yaitu

1. Media yang tidak diproyeksikan: papan tulis, papan flip, grafik, peta, gambar, realita, model tiruan, papan pameran, dan diorama.

2. Media yang diproyeksikan: OHP, slide, dan proyektor.

3. Media audio: pita kaset, rekaman piringan, dan compact disc.

4. Media film dan video (audio-visual): kaset vedio (DVD dan sejenisnya)

5. Multimedia: koleksi berbagai tipe media yang terikat dalam satu topik tertentu. Misalnya modul pembelajaran yang berupa teks berisi soal-soal dilengkapi dengan gambar dan program powerpoint.

6. Media berbasis komunikasi: teleconference, dan kuliah jarak jauh (telelecture).

Menurut Akhmad Sudrajat, terdapat empat jenis media belajar, di antaranya : 1. Media Visual : grafik, diagram, chart, bagan, poster, kartun, komik 2. Media Audial : radio, tape recorder, laboratorium bahasa, dan sejenisnya 3. Projected still media : slide; over head projektor (OHP), in focus dan sejenisnya 4. Projected motion media : film, televisi, video (VCD, DVD, VTR), komputer dan sejenisnya. 


\subsection{Fungsi Media Pembelajaran}

Sadiman, dkk (1990) menyampaikan fungsi media (media pendidikan) secara umum, adalah sebagai berikut: (i) memperjelas penyajian pesan agar tidak terlalu bersifat visual; (ii) mengatasi keterbatasan ruang, waktu, dan daya indera, misal objek yang terlalu besar untuk dibawa ke kelas dapat diganti dengan gambar, slide, dsb., sedangkan peristiwa yang terjadi di masa lalu bisa ditampilkan lagi lewat film, video, fota atau film bingkai; (iii) meningkatkan kegairahan belajar, memungkinkan siswa belajar sendiri berdasarkan minat dan kemampuannya, dan mengatasi sikap pasif siswa; dan (iv) memberikan rangsangan yang sama, dapat menyamakan pengalaman dan persepsi siswa terhadap isi pelajaran.

Penggunaan media dalam kegiatan belajar mengajar memiliki pengaruh yang besar terhadap alat-alat indera. Terhadap pemahaman isi pelajaran, secara nalar dapat dikemukakan bahwa dengan penggunaan media akan lebih menjamin terjadinya pemahaman yang lebih baik pada siswa. Pebelajar yang belajar lewat mendengarkan saja akan berbeda tingkat pemahaman dan lamanya "ingatan" bertahan, dibandingkan dengan pebelajar yang belajar lewat melihat atau sekaligus mendengarkan dan melihat. Media pembelajaran juga mampu membangkitkan dan membawa pebelajar ke dalam suasana rasa senang dan gembira, di mana ada keterlibatan emosianal dan mental.

\subsection{Pembelajaran Berbasis Multimedia}

Pembelajaran Multimedia adalah suatu kegiatan belajar mengajar di mana dalam penyampaian bahan pelajaran yang disajikan kepada siswa, guru menggunakan atau menerapkan berbagai perangkat media pembelajaran. Adapun media pembelajaran itu sangatlah beraneka macam, baik itu dalam bentuk media cetak, media/alat peraga ataupun media elektronik (Fidiatno, 2007). 
Media cetak sudah sangat lazim bagi guru maupun siswa, media cetak meliputi buku paket, buku referensi, majalah, tabloid, koran, atlas / peta atau mediamedia cetak lainnya. Alat peraga meliputi model / bentuk, globe, relief, gambar bagan, dan alat musik. Sedang media elektronik meliputi TV, Radio, Tape Recorder, OHP, Komputer, LCD Proyektor, Slide.

\subsection{Interaktif}

CD Interaktif merupakan sebuah media yang menegaskan sebuah format multimedia dapat dikemas dalam sebuah CD (Compact Disk) dengan tujuan aplikasi interaktif di dalamnya. CD ROM (Read Only Memory) merupakan satu-satunya dari beberapa kemungkinan yang dapat menyatukan suara, video, teks, dan program dalam CD.

Kemudian dalam program talk show e-Lifestyle yang ditayangkan Metro TV pada 9 Agustus 2003 pukul 09.00 WIB disebutkan bahwa CD Interaktif adalah sebuah $\mathrm{CD}$ yang berisi menu-menu yang dapat diklik untuk menampilkan sebuah informasi tertentu.

Dari sini jelas bahwa sistem interaktif yang dipakai CD Interaktif sama persis dengan sistem navigasi pada internet, hanya yang berbeda di sini adalah media yang dipakai keduanya. CD Interaktif memakai media off line (tanpa jaringan) berupa CD sementara internet memakai media on line (aktif di jaringan). Bentuk CD Interaktif dengan tampilan yang tetap menarik hanya dapat digunakan pada lokal satu unit PC (Personal Computer) saja. Sedangkan internat merupakan sebuah media memiliki banyak keunggulan dibandingkan dengan media lain, dimana media ini demikian mudah digunakan, memiliki kecepatan tinggi, dan yang paling penting bahwa internet memiliki jaringan yang mendunia. Hal ini yang menjadikan adanya korelasi antara internet dan CD Interaktif (Beni, http://deskomers01.com).

Membuat halaman CD interaktif tak ubahnya seperti membuat halaman web karena secara umum halaman web sama dengan halaman 
CD interaktif, hanya medianya saja yang berbeda. Dengan demikian kaidah-kaidah yang ada pada CD Interaktif dan web adalah sama. Seorang desainer menggunakan elemen-elemen pokok agar sebuah desain dapat secara efektif menyampaikan tujuannya. Elemen-elemen yang digunakan tersebut antara lain adalah tipografi, simbolisme, ilustrasi dan fotografi (Istanto, 2001). Sedangkan menurut Budi Sutedjo Dharma Oetomo (Oetomo, 2001) menyatakan ada 10 unsur yang dapat digunakan untuk merancang sebuah halaman CD Interaktif yang cantik dan artistik, yaitu huruf, warna, gambar, model kartun, foto, animasi, tiga dimensi, bentuk-bentuk geometri, tekstur, dan manusia. Dari berbagai pendapat itu maka dapat disimpulkan ada beberapa elemen yang sangat vital dalam proses perancangan sebuah CD Interaktif yang artistik dan efektif, diantaranya adalah: tipografi, simbolisme, ilustrasi, warna, fotografi, animasi, nuansa, dan halaman depan (Beni, http://deskomers01.com)..

\subsection{Gaya}

Di dalam ilmu fisika, gaya atau kakas adalah apapun yang dapat menyebabkan sebuah benda bermassa mengalami percepatan. Gaya memiliki besar dan arah, sehingga merupakan besaran vektor. Satuan SI yang digunakan untuk mengukur gaya adalah Newton (dilambangkan dengan $\mathrm{N}$ ).

Bergeraknya suatu bendadapat dipengaruhi oleh beberapa gaya antara lain gaya gesekan, gaya berat dan gaya magnet. Berikut ini adalah definisi dari ketiga gaya di atas, yaitu :

\section{Gaya Gesekan}

Gaya gesekan adalah gaya yang ditimbulkan oleh dua benda yang bergesekan atau bersentuhan yang besarnya sama dan berlawanan arah. Sebagai contoh adalah gaya gesekan yang terjadi antara ban mobil dengan permukaan jalan, gaya gesekan yang terjadi antara udara dan mobil yang dapat menghambat gerak mobil. 


\section{Gaya Berat}

Berat adalah gaya gravitasi bumi yang bekerja pada suatu benda, dimana berat sama dengan hasil kali massa dengan percepatan gravitasi. Karena massa benda dimana saja tetap, maka berat benda sangat bergantung pada percepatan gravitasi dimana benda berada. Percepatan gravitasi di Bumi, Bulan, dan di Angkasa Luar berbeda. Jadi berat benda berbeda-beda tergantung pada percepatan gravitasi tempat benda berada.

\section{Gaya Magnet}

Medan magnet, dalam ilmu Fisika, adalah suatu medan yang dibentuk dengan menggerakan muatan listrik (arus listrik) yang menyebabkan munculnya gaya di muatan listrik yang bergerak lainnya. Hasil kerja Maxwell telah banyak menyatukan listrik statis dengan kemagnetan, yang menghasilkan sekumpulan empat persamaan mengenai kedua medan tersebut. Namun, berdasarkan rumus Maxwell, masih terdapat dua medan yang berbeda yang menjelaskan gejala yang berbeda. Einsteinlah yang berhasil menunjukkannya dengan relativitas khusus, bahwa medan listrik dan medan magnet adalah dua aspek dari hal yang sama (tensor tingkat 2), dan seorang pengamat bisa merasakan gaya magnet di mana seorang pengamat bergerak hanya merasakan gaya elektrostatik. Jadi, dengan menggunakan relativitas khusus, gaya magnet adalah wujud gaya elektrostatik dari muatan listrik yang bergerak, dan bisa diprakirakan dari pengetahuan tentang gaya elektrostatik dan gerakan muatan tersebut (relatif terhadap seorang pengamat).

\subsection{Hukum-Hukum Newton}

Hukum Newton adalah hukum sains yang ditemukan oleh Isaac Newton mengenai sifat gerak benda. Hukum-hukum ini merupakan dasar dari mekanika klasik. 


\section{Hukum Newton I}

HUKUM NEWTON I disebut juga hukum kelembaman (Inersia).

Sifat lembam benda adalah sifat mempertahankan keadaannya, yaitu keadaan tetap diam atau keaduan tetap bergerak beraturan.

\section{DEFINISI HUKUM NEWTON I :}

Setiap benda akan tetap bergerak lurus beraturan atau tetap dalam keadaan diam jika tidak ada resultan gaya (F) yang bekerja pada benda itu, jadi:

$\mathrm{S} F=0 \quad \mathrm{a}=0$ karena $\mathrm{v}=0($ diam $)$, atau $\mathrm{v}=\operatorname{konstan}(\mathrm{GLB})$

\section{HUKUM NEWTON II}

Percepatan yang diperoleh benda bila dikerjakan gaya padanya akan berbading lurus dengan resultan gaya-gaya yang bekerja pada benda tersebut, dengan suatu konstanta pembanding yang merupakan ciri khas dari benda.

HUKUM NEWTON

III

Jika suatu benda mengerjakan gaya pada benda kedua maka benda kedua tersebut mengerjakan juga gaya pada benda pertama, yang besar gayanya = gaya yang diterima tetapi berlawanan arah. Perlu diperhatikan bahwa kedua gaya tersebut harus bekerja pada dua benda yang berlainan.

\section{DESAIN SISTEM}

Dalam pengembangan CD multimedia interaktif untuk pembelajaran gaya dan tekanan ini meliputi 6 tahapan, yaitu: konsep, disain, pengumpulan material, pembuatan (assemby), testing, dan distribusi (Luther, 1994). Tahapan-tahapan tersebut dapat dilihat pada Gambar 3 berikut ini. 


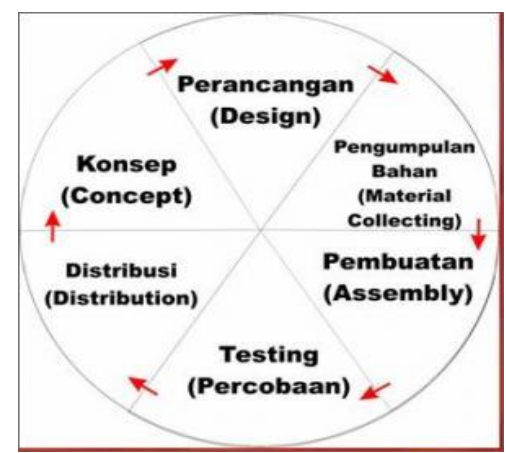

Gambar 1: Tahap pengembangan aplikasi multimedia interaktif menurut Luther (1994)

\section{Konsep (Concept)}

Tahap konsep merupakan tahap awal dari pengembangan multimedia interaktif. Dalam tahap ini yang paling utama adalah penentuan ide dasar program yang akan dikembangkan.

\section{Perancangan (Desain)}

Pada tahap ini akan dibuat bagan alir (Flow Chart) yang menggambarkan struktur dari aplikasi multimedia interaktif untuk pembelajaran gaya dan tekanan yang dibuat secara rinci dan pembuatan storyboard untuk pemetaan elemen-elemen atau bahan (material) multimedia pada setiap layar aplikasi multimedia.

\section{Pengumpulan bahan materi program (Material Collecting)}

Pada tahap ini dilakukan pengumpulan bahan (material) seperti: clipart, image, animasi, audio, berikut pembuatan grafik, foto, audio, dan lainlain yang menunjang aplikasi mutimedia untuk pembelajaran gaya dan tekanan ini.

\section{Pembuatan (Assembly)}

Tahap assembly merupakan tahap dimana seluruh objek multimedia dibuat. Dalam tahap ini objek material seperti text, gambar, audio, video 
dan material lain yang telah dikumpulkan dijadikan sebuah program yang terstruktur sesuai dengan storyboard dan flow chart yang telah dibuat sebelumnya.Dalam hal ini, software yang digunakan adalah Macromedia Flash.

\section{Percobaan (Testing)}

Testing dilakukan setelah tahap pembuatan selesai seluruhnya. Pertamatama dilakukan testing secara modular untuk memastikan apakah hasilnya seperti yang diinginkan. Selanjutnya jika ada kesalahan, program tersebut diperbaiki. Jika sudah sesuai maka dapat berlanjut pada tahap berikutnya.

\section{Distribusi (Distribution)}

Tahapan ini maksudnya adalah menyimpan data hasil program ke dalam media yang dapat dikonsumsi oleh banyak orang. Media yang digunakan biasanya berupa CD-ROM. Proses ini dinamakan pula sebagai proses pembakaran CD (burning).

\section{HASIL DAN PEMBAHASAN}

Pada tahap pengembangan akan dihasilkan sebuah aplikasi berbasis multimedia untuk pembelajaran gaya dan tekanan yang ditujukan untuk siswa SMP kelas VII. Aplikasi ini dikemas dalam bentuk CD Interaktif. Ketika pertama kali CD dijalankan di komputer, maka akan muncul layar intro dengan durasi sekitar 30 detik seperti yang terlihat pada Gambar 2 berikut ini : 


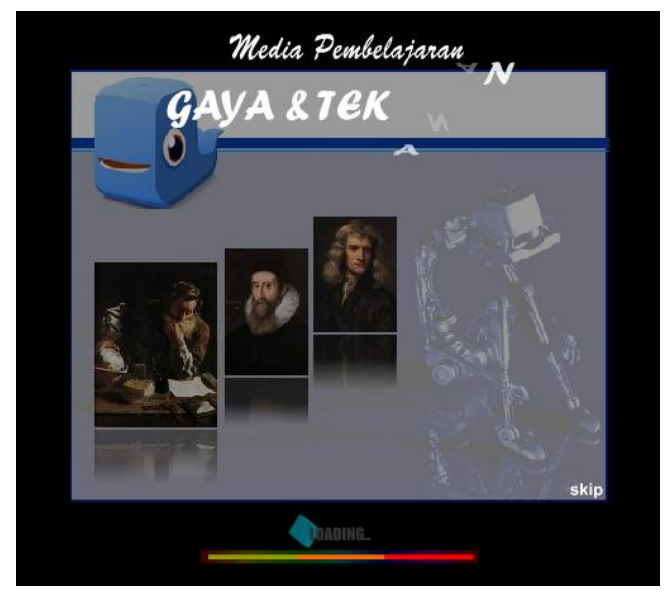

Gambar 2: Tampilan layar intro

Setelah layar intro akan muncul tampilan awal dari aplikasi multimedia seperti pada Gambar 3 berikut :

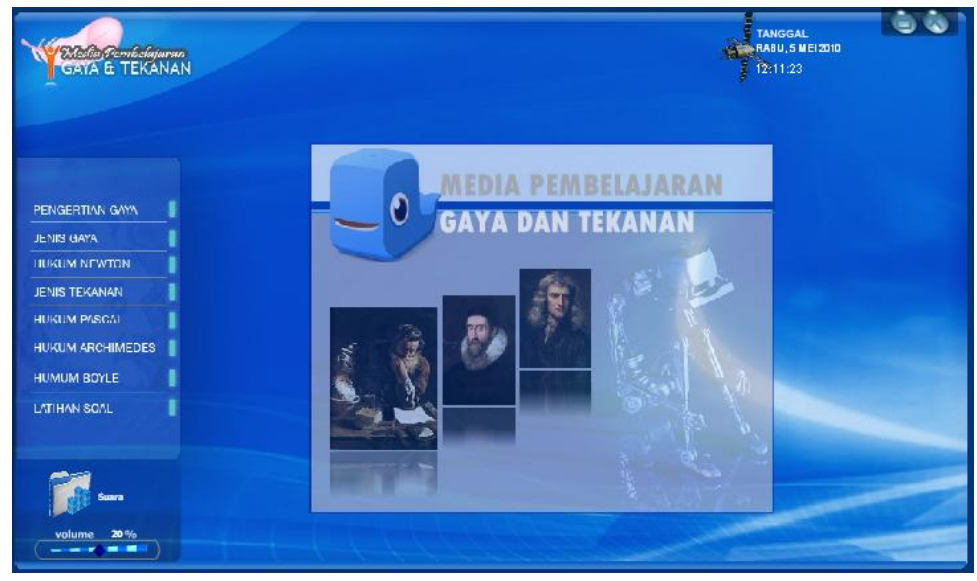

Gambar 3: Tampilan awal aplikasi

Pada tampilan awal ini, disajikan menu-menu yang dapat digunakan untuk mengakses informasi-informasi atau materi pembelajaran gaya dan tekanan. Adapun menu-menu tersebut adalah pengertian gaya, jenis gaya, hukum newton, jenis tekanan, hukum archimedes, hukum pascal, hukum boyle dan menu untuk latihan soal. Informasi/materi dalam media ini disajikan dalan bentuk teks yang dilengkapi dengan animasi, video, audio dan grafik hasil evaluasi. 
Ketika salah satu menu diklik sebagai contoh adalah menu pengertian gaya, maka akan ditampilkan layar seperti pada Gambar 4.

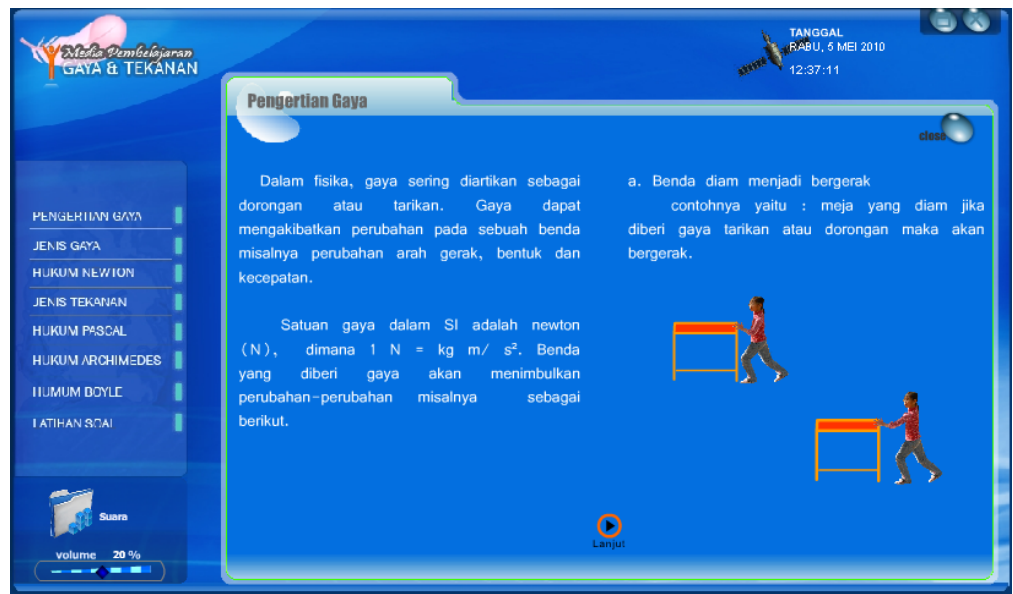

Gambar 4: Penyajian materi untuk menu pengertian gaya

Sedangkan bentuk penyajian materi hukum newton dapat dilihat pada Gambar 5.

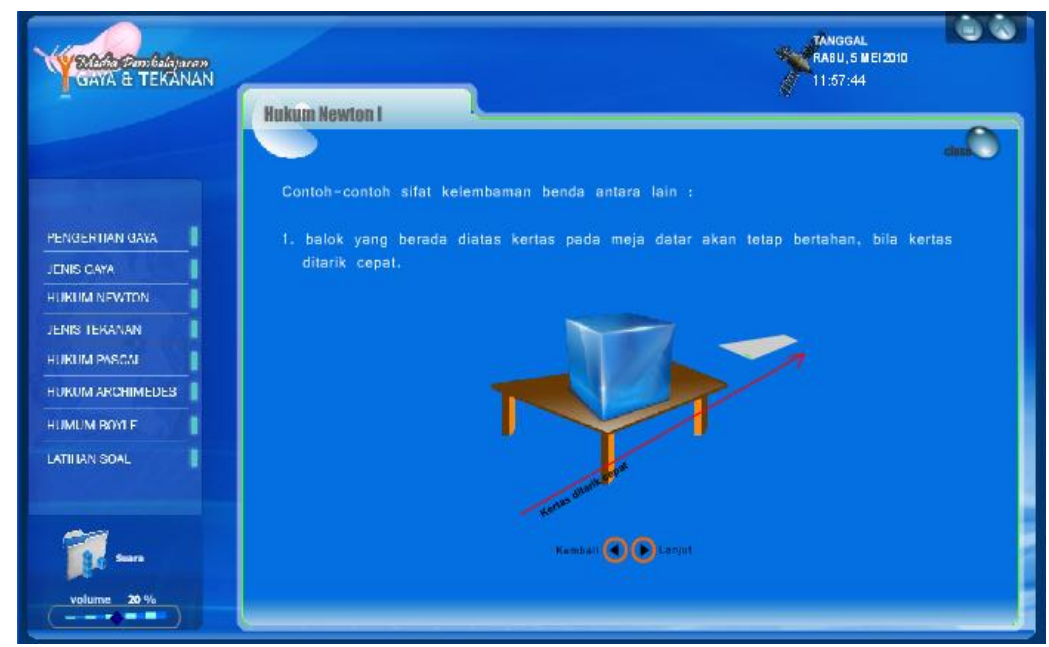

Gambar 5: Penyajian materi untuk menu Hukum Newton

Dan untuk penyajian materi dari menu-menu yang lain bentuknya hampir sama. Media pembelajaran ini juga dilengkapi dengan latihan soal untuk evaluasi siswa terhadap materi ajar dari gaya dan tekanan. Soal yang 
disediakan sebanyak 20 buah yang dilengkapi dengan kunci jawaban dan pembahasan. Dari 20 soal tersebut, yang ditampilkan hanya 10 soal yang kemunculannya diacak. Jadi kemungkinan jenis soal yang dikerjakan oleh dua siswa yang berbeda akan berbeda pula,atau kemungkinan juga sama. Adapun tampilan awal dari evaluasi ini adalah seperti terlihat pada Gambar 6. Pada layar ini, siswa harus menuliskan namanya sebelum mengerjakan soal. Setelah nama ditulis, siswa dapat mengklik tombol Enter.

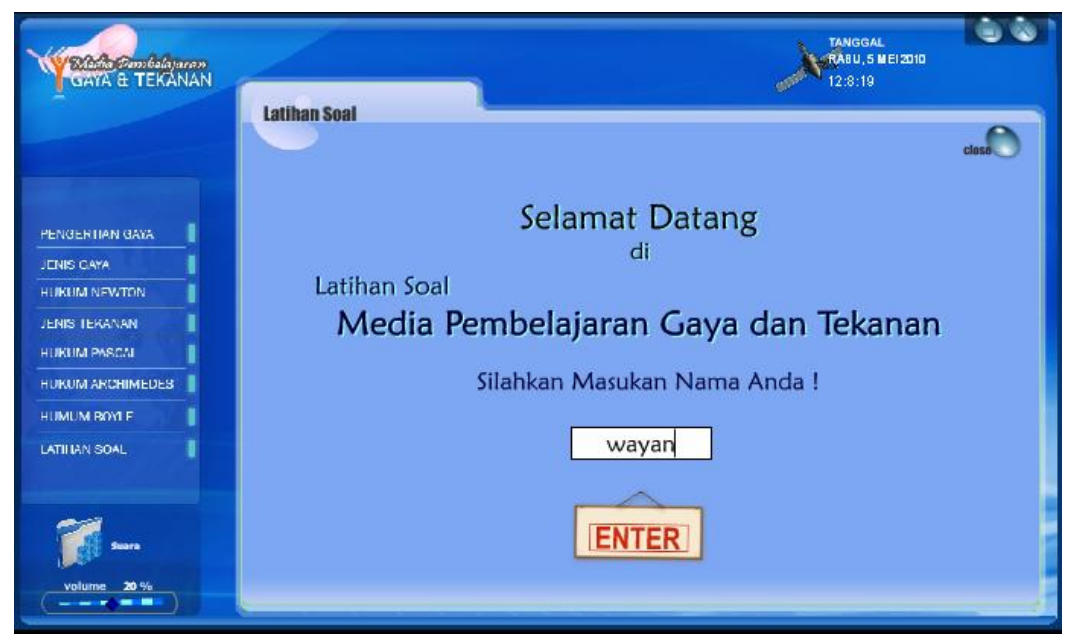

Gambar 6: Tampilan awal untuk menu soal latihan

Selanjutnya media akan menyajikan soal pertama untuk dikerjakan siswa. Dimana tampilannya seperti yang terlihat pada Gambar 7. Jenis soal yang disajikan berbentuk soal obyektif dengan empat buah pilihan. Siswa dapat menjawab soal evaluasi dengan cara mengklik salah satu pilihan yang ada. Ketika siswa mengklik salah satu pilihan obyektif yang ada sebagai jawaban atas soal evaluasi yang dikerjakan, maka akan langsung disajikan soal berikutnya. Hal yang sama akan terus berlangsung sampai soal nomor 10 ditampilkan. Setelah soal nomor 10 dikerjakan, selanjutnya akan ditampilkan layar hasil evaluasi seperti yang terlihat pada Gambar 8. 


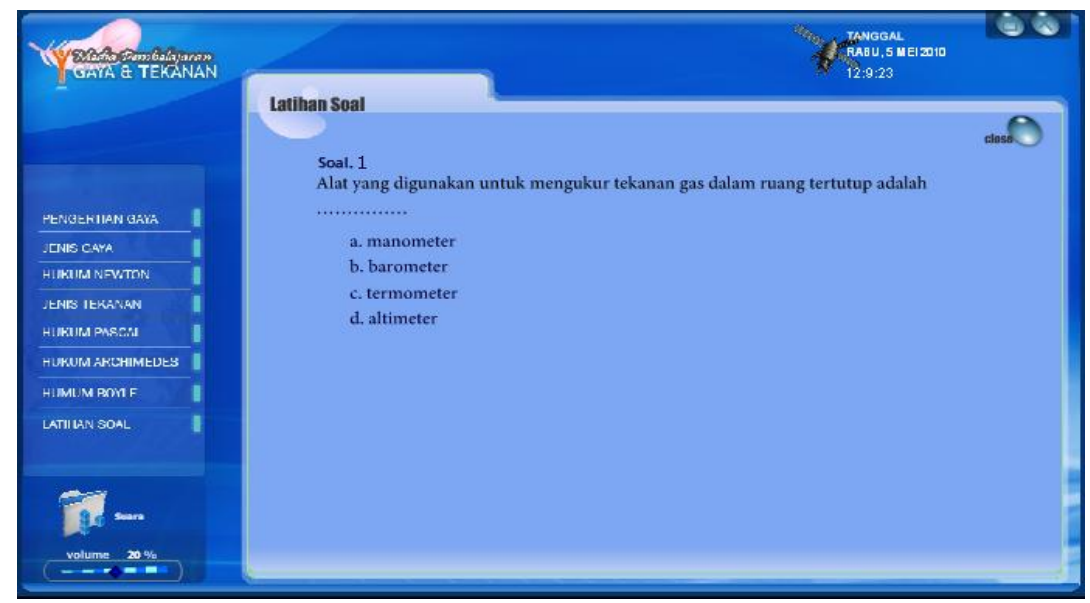

Gambar 7: Tampilan penyajian soal pertama untuk menu soal latihan

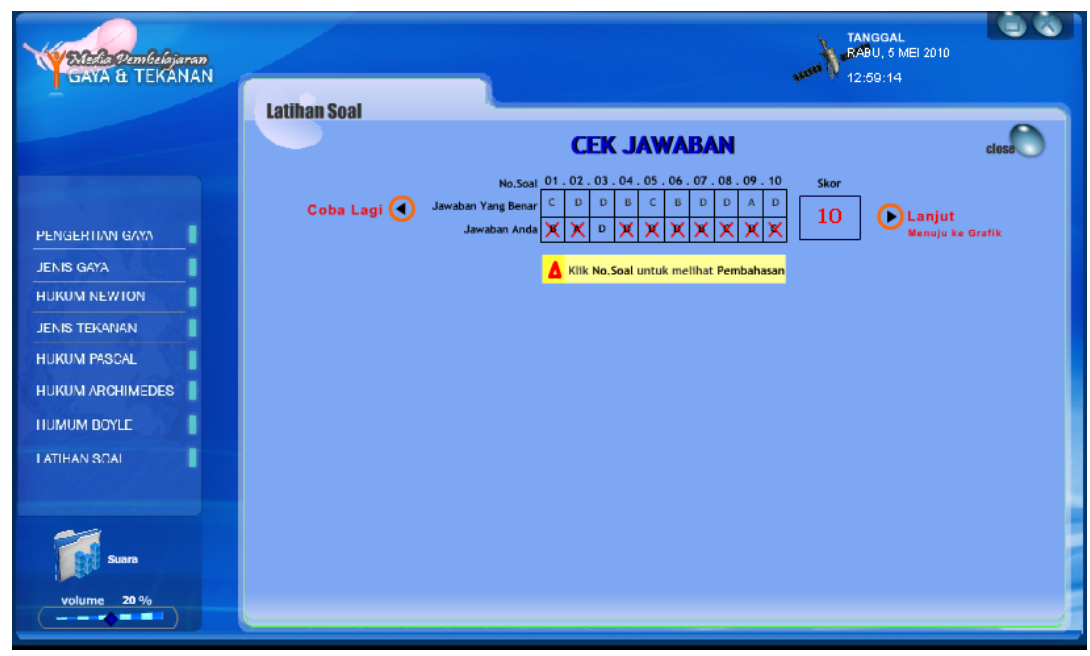

Gambar 8: Tampilan hasil evaluasi yang dilengkapi dengan kunci jawaban

Media ini juga dilengkapi dengan grafik hasil evaluasi siswa. Grafik dapat dilihat dengan mengklik tombol setitiga yang berada di sebelah kanan yang bertuliaskan "lanjut menuju ke grafik". Pada grafik, akan ditampilkan hasil evaluasi lima peserta (siswa) terakhir. 


\section{PENUTUP}

Media Pembelajaran Gaya dan Tekanan Berbasis Multimedia dibangun menggunakan perangkat lunak Macromedia Flash. Media pembelajaran ini dikemas dalam bentuk CD interaktif yang ditujukan untuk siswa SMP kelas VII. Melalui media ini siswa dapat mempelajari materi gaya dan tekanan, dengan sub-sub pokok bahasan yaitu pengertian gaya, jenis-jenis gaya, hukum newton, jenis tekanan, hukum pascal, hukum archimedes, dan hukum boyle. Dalam penyajian materinya, berbentuk teks yang dilengkapi dengan animasi, audio, video dan grafik. Media ini juga dilengkapi dengan soal-soal evaluasi yang dapat digunakan untuk mengukur tingkat penguasaan siswa terhadap pembelajaran gaya dan tekanan. Dengan media ini, siswa dapat mempelajari materi tentang gaya dan tekanan secara mandiri tanpa harus dipandu oleh guru di sekolah. Media ini dapat digunakan siswa untuk belajar dirumah.

\section{DAFTAR PUSTAKA}

Beni, Dani Maroe. Multimedia. http://deskomers01.com/?p=187, diakses pada tanggal 19 april 2010

Dewi, Luisa Rishe Purnama. 2007. Gatra: Media Pembelajaran dan Pengembangan Bahan. USD: Yogyakarta.

Fidiatno, Ides. 2007. Pembelajaran Berbasis Multimedia : Penerapan Perangkat Tik Dalam Pengembangan Kegiatan Belajar Mengajar. http://media.diknas.go.id/media/document/5335.pdf, diakses 10 Februari 2010

Haryanto. 2007. Sains untuk Sekolah Dasar Kelas V. Jakarta: Erlangga.

Istanto, Freddy H. 2001. Potensi dan Kaidah Perancangan Situs Web Sebagai Media Komunikasi visual. Nirmana, Volume 3. No.1 
Lutther, Arc C. 1994. Authoring Interactive Multimedia. Boston : AP Professional.

Sadiman, A.S., Rahardjo, R., Haryono, A., \& Rahadjito. 1990. Media Pendidikan: pengertian, pengembangan dan pemanfaatannya. Edisi 1. Jakarta: Penerbit CV. Rajawali.

Soeparno. 1988. Media Pengajaran Bahasa. Yogyakarta: Intan Pariwara

Sudrajat, Akhmad. 2008. Media Pembelajaran. http://akhmadsudrajat.wordpress.com/ 2008/01/12/mediapembelajaran/, diakses tanggal 6 Februari 2010.

Surjono, Herman Dwi. 1995. Pengembangan computer assisted instruction (CAI) untuk pembelajaran elektronika [Versi elektronik]. Jurnal Kependidikan. No.2 (XXV): 95-106.

Oetomo, Budi Sutedjo Dharma. 2001. "Perspektif e-Business: Tinjauan Teknis, Manajerial, dan Strategi", Yogyakarta : Penerbit Andi Offset. 